\title{
STUDI KRITIS TERHADAP ILMU BALAGHAH KLASIK
}

\author{
Husein Aziz*
}

\begin{abstract}
A bstract: Classical Balaghah has been developed theoretically since the era of B. M u'taz and culminated in the development in the era of al-Q ahir al-J urjani. But since then, if has ceased to improve. In the modern era, this science has only been applied, annotated, redefined and classified. As a consequence, Balaghah turned out to be both dry and static, incapable of further improvement and adaptation to new circumstances. It is in this context that this science should be revisited so that new formulation may be fund.
\end{abstract}

Key words: Classical Balaghah, deconstruction dan reconstruction.

\section{Pendahuluan}

Studi balaghah ${ }^{1}$ yang pada mulanya dimaksudkan untuk menelaah keindahan bahasa alQ ur'an telah tumbuh dan berkembang secara metodologis sejak B. Mu'taz (861-908 M) dengan karyanya al-Badi'sdan al-Farra' Abu Ubaidah, Muammar B. Muthanna (w.207H) dengan kitabnya Ma'ani al-Q ur'an dan memuncak pada zaman Abd al-Q adir al-J urjani (w.471H) dengan kitabnya yang populer Dalaił al-I'jaz dan Asrapal-Balaghah. ${ }^{2}$ Adapun masa-masa sesudahnya tidak ada lagi sarjana yang melakukan penambahan, pengurangan apalagi mengkritisinya dan hanya mempelajari, menerapkan, mengklasifikasikan dan melakukan pensyarahan-pensyarahan. ${ }^{3}$

Di antara ulama yang menerapkan balaghah karya Abd al-Q ahir adalah J ar Allah, Mahmud b. U mar al-Zamakhshari (w.538H) dalam kitab tafsirnya al-Kashshaf: la telah menerapkan semua konsep balaghah yang ditulis Abd al-Q ahir al-J urjani dalam kitab Asrapal-Balaghah dan Dalaił al-I'jaz secara rinci tehadap ayat-ayat al-Qur'an. Bahkan nyaris tiada satupun konsep balaghah yang ditinggalkannya tanpa mendatangkan permisalannya dari ayat-ayat al-Q ur'an. ${ }^{4}$

Adapun di antara ulama yang melakukan peringkasan dan pemadatan adalah Fakhr alDiø, Muhammad b. Umar al-Razì (w. 606H) dalam kitabnya Nihayat al-ljaz fi Đirayazal-I'jaz, sedangkan Siraj al-Din, Abu Ya'qub, Yusuf b. Muhammad b. Ali al-Sakaki (w. 626) dan al-Khatib al-Qazwiniłw. 739H ) yang mempunyai nama lengkap J alal al-Din, Muhammad b. al-Qadi, Sa'd al-Diø, Abd al-Rahman dalam kitabnya al-Talkhisatau al-I\&łhh hanya melakukan klasifikasi dan pendefinisian secara detail dalam kitabnya al-Miftah, $\beta$ Peringkasan ini juga dilakukan oleh Diyas al-Din b. al-Athis (w. 637H) dalam kitabnya al-Mathal al-Sa'ýr atau al-J ami' al-Kabir. Keduaduanya mengikuti jejak al-Sakaki dan al-Khatijo al-Qazwini§.

* Fakultas Adab IAIN Sunan Ampel Surabaya

${ }^{1}$ Ilmu Balaghah adalah ilmu tentang teori sastra Arab yang meliputi ilmu ma'ani łkomposisi), ilmu bayan dan ilmu badi' (gaya bahasa).

${ }^{2}$ Shawqi D фyyif, al-Balaghah Tatłwwur wa Tarikh (Kairo: Dasal-Ma'arif, 1965), 271.

${ }^{3}$ Ibid., 278.

${ }^{4}$ Ibid., 243.

${ }^{5}$ Ibid., $286-287$

${ }^{6}$ Ibid., 290 
Dari uraian panjang di atas dapat diambil pengertian bahwa kajian ilmu balaghah telah memuncak dan terhenti di zaman Abd al-Q ahir al-J urjani. Akibatnya balaghah tidak lagi mengikuti perkembangan zaman dan menjadi kaidah-kaidah yang kering, statis tidak berkembang sejak zaman itu sampai sekarang. Oleh karena itu membaca ulang balaghah yang mengantarkan kepada rekonstruksi diperlukan karena balaghah klasik telah berumur lebih dari seribu tahun, sebab manusia dalam waktu selama itu telah mengalami berbagai perubahan dan perkembangan peradaban sedemikian rupa yang menjadikan balaghah klasik tidak lagi mampu mengikuti perkembangan zaman kekinian. Kaidah-kaidah balaghah klasik itu ibarat senjata konvensional seperti pedang dan to mbak yang digunakan orang-orang kuno, suatu hal yang tidak layak lagi untuk digunakan manusia modern dalam pertempuran dalam menghadapi senjata-senjata modern. Sementara seorang muslim sebagai hamba Allah di bumi memiliki amanah menyampaikan ajaran dan nilai-nilai Islam kepada orang dan bangsa lain, yang tentu saja membutuhkan sarana yang dapat diandalkan sesuai dengan bahasa zamannya sehingga memiliki pengaruh seperti yang diharapkan.

Tulisan ini mencoba untuk melihat beberapa kelemahan kaidah balaghah klasik sebagai langkah awal melakukan reformulasi kaidah-kaidah baru yang sejalan dengan perkembangan zaman kekinian. Apa lagi sebagaimana dikatakan Abduh Abd al-Aziz bahwa balaghah dimaksudkan tidak hanya untuk mengetahui keindahan sastra sebagaimana yang telah dilakukan para pakar balaghah klasik dalam kaitannya dengan maksud mengetahui keindahan al-Q ur'an, akan tetapi juga dimaksudkan untuk membantu menulis dengan bahasa yang kuat dan efektif (baligh). ${ }^{7}$

Dari deskripsi singkat di atas, maka kajian ini memusatkan perhatiannya pada dua persoalan utama, yaitu beberapa kelemahan balaghah klasik baik dari ilmu ma'ani>bayan dan badi'?

Sumber data dalam penelitian ini adalah balaghah klasik, utamanya AsrapBalaghah dan Dalaił al-I'jaz, karya Abd al-Q ahir al-J urjani dan J awabir al-Balaghah fi>llm al-Ma'ani wa albayan wa al-Badi's karya Ahmad al-H ashimi> Semua data dihimpun melalui observasi dan pengamatan langsung dengan membaca, menelaah secara seksama terhadap karya-karya balaghah klasik tersebut dari bab ke bab yang lain mulai ilmu ma'ani,ybayan sampai pada ilmu badi's Data-data yang tehimpun dianalisa dengan menggunakan dua langkah. Pertama, mencari kejanggalan-kejanggalan yang ada di dalamnya dengan menggunakan metode komperatif, yaitu dengan membandingkan antara satu kaidah dengan kaidah yang lain dan pada sisi yang lain membandingkan dengan apa yang ada di dalam al-Q ur'aß sebagai kitab yang diterima semua muslim untuk dijadikan ukuran. Kedua, membandingkan dengan apa yang ada dalam komposisi, teori-teori dan gaya bahasa modern baik yang tertulis dalam bahasa Indonesia maupun dalam bahasa Inggris. Selanjutnya mengenai bentuk penelitian dalam kaitannya dengan wilayah sumber data yang dijadikan sebagai obyek penelitian, penelitian ini bersifat populatif. $\mathrm{H}$ al ini dimaksudkan supaya memiliki signifikansi yang lebih maksimal dalam kaitannya dengan reformulasi ilmu balaghah sejalan dengan komposisi, teori sastra dan gaya bahasa modern.

\footnotetext{
${ }^{7}$ Abduh Abd al-Aziz al-Qalqalah, "al-Dawr al-Balaghis dalam J ournal al-Faysæal, ed. 46 (Saudi: al-Mamlakah alArabiyah al-Saudiyah, 1982), 73.
} 


\section{Beberapa Kelemahan Kaidah Balaghah Klasik}

Balaghah klasik itu bila dikaji secara seksama, maka akan ditemukan beberapa kerancuan bahkan bertentangan antara kaidah yang satu dengan yang lainnya. Di antaranya adalah dalam bab pembahasan tentang gaya bahasa perbandingan atau yang dikenal dengan tashbih ${ }^{\beta}$ Balaghah klasik mendefinisikan, tashbih/baligh adalah tashbih/yang tidak disebutkan sarana pentashbihannya ('adat al-tashbih) dan tidak pula titik persamaannya (wajh al-shibh). Tashbih semacam ini dinilai sebagai tashbihyyang lebih baik, kuat dan efektif dari pada bentuk tashbihy yang disebutkan sarana tashbibmya dan titik persamaannya ${ }^{9}$ A kan tetapi pada sisi lain balaghah klasik mendefinisikan bahwa tashbih/tamthil, suatu tashbih/yang titik persamaannya diambil dari berbagai sisi yang beragam (tidak tunggal) dan disebutkan dinilai sebagai tashbih/yang lebih efektif, kuat dan lebih baik dari bentuk tashbih/selainnya. Demikian itu karena adanya penyebutan secara rinci titik persamaan di dalamnya sehingga lebih menyentuh jiwa dan lebih mengena. ${ }^{10}$

Fakta sebagaimana dikemukakan di atas menunjukkan bahwa di sana ada pertentangan (paradoks) antara satu definisi dengan definisi yang lainnya dan pada saat yang sama menunjukkan adanya kesalahan ukuran. Pertentangan itu tampak dengan jelas ketika ahli balaghah melihat bahwa tashbihjyang tidak disebutkan sarana pentashbihan dan titik persamaannya adalah lebih baik dari bentuk-bentuk tashbih/selainnya. Namun pada tempat yang lain mereka melihat bahwa tashbihyang menyebutkan berbagai ragam persamaan secara rinci dinilai sebagai tashbih\}yang lebih baik karena lebih kuat dan lebih menyentuh jiwa pembacanya. J elas hal ini menunjukkan adanya paradoks dalam pendefinisian kaidah.

Selanjutnya kesalahan ukuran tampak pada pendapat para ahli balaghah klasik yang berpendapat bahwa tashbih/yang tidak menyebutkan sarana perbandingan dan tidak pula menyebutkan titik persamaannya lebih kuat dan lebih efektif dari bentuk-bentuk tashbih\} selainnya. Bila ukuran ini diterima, tentu bentuk-bentuk tashbibyyang terdapat dalam al-Qur'an lebih rendah tingkat kebalaghahannya karena bentuk-bentuk tashbih/dalam al-Qur'an pada galibnya menyebutkan sarana pentashbibian dan titik persamaannya.

Pada tataran yang sama ditemukan pula dalam ilmu Badi'ssuatu kejanggalan. Misalnya para ahli balaghah klasik melihat bahwa sajak terbaik adalah sajak yang ungkapan kalimatnya sepadan, kemudian ungkapan kalimat kedua lebih panjang, begitu juga ungkapan ketiga lebih panjang. ${ }^{12}$ Sajak yang menyalahi ukuran ini dinilai sebagai sajak yang tidak baik. Demikian itu karena menurutnya seorang yang mendengarkan ungkapan atau ujaran yang lebih pendek dari kalimat sebelumnya akan merasa kehilangan keindahan. ${ }^{12}$

Persoalannya sekarang adalah apakah asumsi-asumsi yang dikemukakan para ahli

\footnotetext{
${ }^{8}$ Tashbih adalah suatu gaya bahasa yang terdiri dari empat unsur; M ushabbah (yang disamakan), Mushabbah bih (yang disamai), Adat tashbih (sarana untuk menyamakan) dan wajh al-shibh (titik persamaan) Lihat Bakri Syeh Amin, al-Balaghah fi đoxawbiha al-J adid, 'Ilm al-Bayan (B eirut: Dasal-Thaqafah al-Islamiyah, 1979), 17.

${ }^{9}$ A hmad al-Hashimi>> awa?hir al-Balaghah fi al-M a'ani wa al-Bayan wa al-Badi' (Kairo:Maktabah al-Tijakiyah, 1969), 70. Lihat pula Abd al-Q ahair al-J urjani, Asrapal-Balaghah (Kairo: Isa al-Babial-Halabi, 1939), 245.

${ }^{10}$ Ibid., 265.

${ }^{11}$ Ahmad, Jawabir, 405 - 406.

12 Ibid., 406.
} 
balaghah klasik itu didukung pengetahuan tentang daya tangkap manusia? Apakah benar respons manusia terhadap suatu keindahan suatu ungkapan kalimat itu tertumpu pada bentuk ungkapan yang lebih panjang, kemudian ungkapan kalimat yang lebih panjang dari keduanya yang tersebut sebelumnya?

Tolak ukur yang dipergunakan ahli balaghah klasik seperti dikemukakan di atas tidak hanya bertentangan dengan prinsip rasa seni keindahan, ${ }^{13}$ akan tetapi juga berlawanan dengan kebalaghahan al-Qur'an itu sendiri. Dalam al-Qur'an banyak ditemukan bentuk-bentuk ungkapan bersajak dengan ungkapan pendek, kemudian panjang, kemudian pendek lagi dan pada suatu saat sepadan dan pada kali yang lain berkutat antara panjang dan pendek.

Kelemahan lain dari balaghah klasik adalah kajiannya yang bersifat partikularistik dan tidak bersifat universal. Balaghah klasik dalam ilmu al-ma'ani memfokuskan perhatiannya pada kata tunggal. Itu pun terbatas pada permasalahan pokok kalimat dan predikat dan batasanbatasannya, mulai dari aspek penyebutan (al-dhikr), pembuangan (al-hadzf), mendahulukan (al-taqdim), mengakhirkan (al-ta'khir), kata yang menunjuk makna khusus (ma'rifah) dan kata yang mengacu pada makna umum (nakirah). IImu ma'ani ini sama sekali tidak menyinggung persoalan paragraf atau alenia. Sebagai dampaknya dalam kitab-kitab agama klasik tidak dijumpai alenia yang berfungsi memudahkan pemahaman. Selanjutnya dalam ilmu al-bayan dibicarakan persoalan tashbih)dengan segala ragamnya, majaz al-isti'arah al-tasyihiyah (metafora), majaz alisti'arah al-makniyah (personifikasi), majaz al-isti'arah al-tamthiliyah (pribahasa), majaz mursal serta kinayah (kiasan). Sementara pada ilmu badi'>dikaji hal-hal yang memperindah kata dan makna seperti sajak, jinas (persamaan bunyi), tibaq (gaya bahasa tarik menarik), dan lain sebagainya.

Semua pembahasan balaghah klasik tidak melampaui kajian kosakata dan kalimat. Padahal suatu teks sastra, keindahannya menurut Mahmud al-Bustani tidak terbatas pada bentuk kalimatkalimat atau ayat-ayat mandiri. Akan tetapi meliputi semua kalimat-kalimat dan ayat-ayat yang saling berkaitan satu dengan yang lainnya dalam suatu bangunan arsitektur tertentu dari suatu tatanan pemikiran-pemikiran berikut situasi dan kondisinya. ${ }^{14}$

Titik kelemahan lain dari balaghah klasik adalah tidak membahas semua bentuk ungkapan kalimat. Hal itu dapat dilihat dari tidak menyinggungnya kajian tentang kisah. Padahal kisah sebagaimana maklum memiliki wilayah yang luas dalam teks-teks al-Qur'an seperti kisah nabi Yusuf, Ash al-Kahf (penghuni gua), kisah nabi Musa dan lain sebagainya. Namun demikian unsur i'jaz al-Q ur'an yang cukup penting ini diabaikan. Padahal sebagaimana telah disebutkan bahwa para ahli balaghah menyatakan bahwa balaghah dimaksudkan pada mulanya untuk mengetahui kei'jazan al-Qur'an.

Kelemahan-kelemahan itu sebagaimna tersebut di atas mendorong perlunya melihat ulang balaghah klasik yang nantinya mengantarkan pembentukan dan penyusunan balaghah baru yang sesuai dengan perkembangan bahasa kekinian pada satu sisi dan pada sisi lain sesuai dengan bahasa al-Qur'an.

${ }^{13}$ Mahmud al-Bustani, "al-B alaghah al-H adithah fi D $\$$ w' al-Manhaj al-Islami”, dalam J ournal Risalah al-Thaqalayni ed. Vi, 1998, 236.

${ }^{14}$ al-Bustani, al-Balaghah, 227. 


\section{Reformulasi Balaghah Klasik}

Balaghah sebagaimana telah dikemukakan di atas dimaksudkan tidak hanya untuk mengetahui kei'jazan al-Q ur'an tetapi juga untuk membantu menulis suatu karangan yang baik dan benar. Untuk tercapainya tujuan tersebut menurut al-Bustani kajian balaghah perlu memperhatikan pada beberapa unsur, diantaranya:

a. Unsur Pemikiran

Setiap teks sastra pasti mengandung suatu pemikiran tertentu di balik pembentukannya yang disebut sebagai tema. Setiap pemikiran dalam sastra harus mengikuti kaidah-kaidah seni seperti pemilihan, batasan, kesatuan dan keberagaman dan sebagainya. ${ }^{15}$ Misalnaya surat al-Kahf, ia mengandung pemikiran khusus, yaitu sikap menolak hidup mewah di dunia. b. Topik

Pemikiran pokok dari suatu teks sastra diwujudkan dalam bentuk topik -topik yang menjadi pokok-pokok kajiannya. Artinya sebuah teks sastra tentu mengandung topik-topik yang menjadi kajiannya. Topik-to pik ini mematuhi pada prinsip-prinsip seni seperti pemilihan, kesatuan, keberagaman, penentuan sosok, peristiwa, dan latar atau panorama. ${ }^{16} \mathrm{H}$ al ini dalam surah al-Kahf tercermin dalam (a) kisah penghuni gua untuk menkonkretkan konsep penolakan hidup mewah (b) kisah pemilik dua kebun yang terpesona oleh kemewahan hidup sebagai kebalikan dari sikap penghuni gua (c) kisah Musa dengan seorang hamba sọlih; seorang misterius yang menjauhi kehidupan dunia (d) kisah Dhu>al-Q arnayn yang menampilkan sosok terkenal yang menguasai wilayah barat dan timur, akan tetapi ia tidak terpedaya dengan kemewahan hidup dunia.

c. Penataan makna

Pemikiran itu sebagaimana maklum tentu mengandung makna-makna yang tertata dalam akal pikiran dengan pola tertentu, seperti global, rinci, didahulukan, diakhirkan negatif dan positif dan seterusnya, ${ }^{17}$ sehingga menjadi tatanan pemikiran yang sistematis dan logis.

d. Bentuk

Yang dimaksud dengan unsur bentuk adalah bahwa sebuah teks sastra boleh jadi berupa sebuah surah dari surah-surah al-Qur'an, atau hdith Nabi Muhammad saw., makalah, kisah, drama ataupun dalam bentuk refleksi dan lain sebagainya.

e. Pemilihan Kata.

Pemilihan kata adalah kata atau ujaran yang digunakan dalam mengungkapkan makna atau pemikiran dan gagasan tertentu secara cermat, tepat dan benar. Oleh karena itu di sini dituntut untuk mematuhi kaidah-kaidah kebalaghahan seperti kelayakan kata, kejelasan dan kekuatannya, keteraturan, dan keruntutan. ${ }^{18} \mathrm{Di}$ samping juga harus benar menurutaturan tata bahasa, dalam hal ini nahw dan sł̆rrafnya.

\footnotetext{
15 Ibid., 238. Lihat pula Gorys Keraf. Komposisi (Flores: Nusa Indah,1970), 107-108.

${ }_{16}$ Ibid., 238. Lihat pula Liberatus Tengsoe Tjahyono, Sastra Indonesia Pengantar Teori dan A presiasi (Flores: Nusa Indah, 1988), 189.

17 al-Bustani, Risalah, 239.

18 Ibid., 239.
} 
f. Nada (Musikalitas).

Nada adalah semua hal yang berkaitan dengan penataan nada suara kata dan ungkapan yang dimaksudkan untuk membangkitkan rasa merdu. Kemerduan bunyi bahasa dalam sastra dimunculkan lewat persajakan, persamaan bentuk kata (wazn), penggalan kalimat (fasillah), persamaan bunyi kata (jinas) dan keselarasan suara dan pengulangan bunyi-bunyi yang sama. ${ }^{19}$

g. Struktur.

Struktur menurut al-Bustani adalah semua hal yang mengkaji bangunan sebuah teks sastra dari sisi hubungan antar bagian-bagian bangunan teks, seperti pendahuluan, pertengahan dan penutup. Di sini juga dikaji tentang hubungan dari tiap-tiap ungkapan dengan sebelum dan sesudahnya, hubungan antar topik-topik yang ada di dalam suatu teks. Begitu juga hubungan antara berbagai unsur seperti gaya bahasa yang digunakan, nada dan lain sebagainya dengan sebagian yang lainnya atau dengan struktur keseluruhan suatu teks sastra. ${ }^{20}$

\section{Rumusan Kaidah Balaghah.}

Bertitik tolak dari tujuan balaghah sebagaimana yang telah dikemukakan di awal tulisan ini, dan dengan memperhatikan faktor eksternal sastra (al-wasf al-khaniji)dan faktor internal (alwasf al-dakkilip, ada dua hal penting yang perlu dikemukakan sebagai pijakan dalam perumusan studi ilmu balaghah, yaitu (a) persoalan komposisi atau meminjam istilah Abd al-Qahir al-J urjani al-nazam dalam IImu Ma'ani zlan (b) gaya bahasa yang menjadi pembahasan IImu Bayan dan IImu Badi's

Berdasarkan pijakan dua hal tersebut susunan atau rumusan ilmu balaghah menurut Muhammad S $\$$ lih adalah dengan mengawali kajian tentang kata tunggal dilihat dari sisi nada, dan pengaruhnya dalam ungkapan kalimat. Atau jelasnya kecermatan memilih kata yang mewakili makna yang akan disampaikan, b) pembahasan tentang kalimat dengan segala bentuknya mulai dari mendahulukan (taqdim), mengakhirkan (ta'khiø), membuang kata (alhadhf), dan menyebutkan kata (al-dhikr), bentuk ijaz, ${ }^{21}$ dan ithab. Dibicarakan pula dalam bab ini, paragraf dan bagaimana cara menyambung kalimat satu dengan lainnya di samping dikemukakan pula penataan kata berdasarkan keruntutan makna serta permasalahan pokok paragraf; yaitu topic sentence (al-laff) dan controlling idea (nashr murattab). Semua ini merupakan kajian Ilmu Ma'ani_selanjutnya di bagian kedua dibahas tentang gaya bahasa yang digunakan dalam mengungkapkan makna dan pemikiran tersebut mulai dari gaya bahasa tashbih,dengan segala ragamnya, majaz dengan segala macamnya yang berupa majaz al-isti'arah al-tasyihiyah (metafora) atau al-isti'arah al-makniyłah (personifikasi) dan kinayah (kiasan). Dikemukakan pula dalam aspek internal bahasa (intrinsik) ini, penataan nada seperti persajakan, persamaan bunyi

${ }_{19}$ Ibid. Lihat pula Ahmad, J awahir, 356. Lihat pula Tengsoe, Sastra, 34.

${ }^{20}$ Ibid., 239.

${ }^{21}$ Ijaz adalah kalimat yang kata-katanya kurang dari maknanya atau maknanya lebih banyak dari kata-kata yang digunakan. Sebaliknya Ithab, kata-kata yang digunakan lebih banyak dari maknanya. Lihat Bakri Syeh, al-Balaghah, 192-193. 
(jinas) dan lain sebagainya yang dalam ilmu balaghah klasik dibicarakan tersendiri dalam ilmu badi': Selanjutnya diaplikasikannya dalam suatu karya sastra untuk dikaji unsur-unsur keindahan di dalamnya berikut hubungan antara kata dan makna. Pada bagian terakhir dipelajari stylistika seni sastra dengan segala macamnya mulai dari simbolisme, realisme dan seterusnya. ${ }^{22}$

Dengan demikian terbentuklah rumusan baru dengan mengambil yang bermanfaat dari masa lalu, balaghah klasik dan ditambah dengan teori-teori sastra yang berlaku pada era kekinian. Ilmu ma'ani sebagai sarana untuk menata pemikiran dalam alinea dan hubungan alinea satu ke alinea yang lain. Sementara ilmu bayan dan badi'ssebagai sarana memilih kata yang dapat mewakili makna yang disampaikan.

\section{Daftar Rujukan}

Ahmad, Muhammad Khalafullah. al-Fann al-Q asłsiłfi gl-Qur'an al-Karim. Kairo: Maktabah alAngelo, 1960.

Amin, Bakri Syeh. al-Balaghah al-'A rabiłyah fi Thawbiha zl-J adid. Beirut: Das al-Thaqafah alIslamizah, 1979.

Bint Shatis', Aishah Abd al-Rahman. Tafsipal-Bayani \$i al-Q ur'an al-Karim. Kairo: Dasal-Ma'arif, 1977.

Dłyyif, Shawqi>al-Balaghah, Tatąwwur wa Tarikh. Kairo: Dasal-Ma‘akif, 1965.

G orys Keraf. Komposisi. Flores: Nusa Indah, 1970.

al-H ashimi, A hmad. J awahir al-Balaghah. Mesir: al-Maktabah al-Tijakiłah al-Kubra, 1960.

al-J urjani, Abd al-Q ahir. Dalaił al-I,jaz. Kairo: Isaral-Babizal-H alabi, 1939.

- - - - , Asrapal-Balaghah. Kairo: Isaral-Babial-H alabi, 1939.

Leberatus Tengsoe Tjahyono. Sastra Indonesia, Teori dan Apresiasi. Flores: Nusa Indah, 1988. Reid, J oy M. The Process of Composition. Toronto: Prentice H all, 1982.

Zakki, Najib Mahmud. Funun al-Adab. Kairo: Lajnah al-Ta'lifwa al-Tarjamah, 1945.

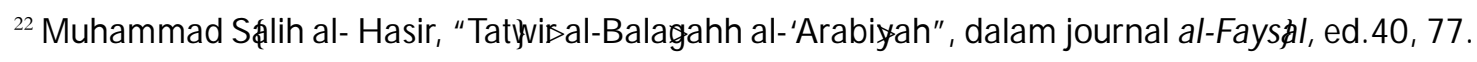

